\title{
Ideological Manipulation in English Translation of Chinese Children's Literature: Case Studies
}

\author{
Shi Ying \\ Department of Foreign Languages, Zhanjiang Preschool Education College, Zhanjiang, PR China \\ Email address: \\ Shiying06140614@126.com \\ To cite this article: \\ Shi Ying. Ideological Manipulation in English Translation of Chinese Children's Literature: Case Studies. International Journal of Applied \\ Linguistics and Translation. Vol. 6, No. 3, 2020, pp. 75-78. doi: 10.11648/j.ijalt.20200603.13
}

Received: August 7, 2020; Accepted: August 17, 2020; Published: August 25, 2020

\begin{abstract}
It is widely accepted that translation is a form of rewriting and it is also true for children's literature. Translation reflects a certain degree of ideological manipulation of the source text in order to either conform to the norms of the target culture or serve some ideological purposes. Since children's literature usually performs both didactic and pedagogical functions, ideological manipulation on children's literature translation is even more significant. Drawing on two English translations of Chinese children's literature works, this article shows how ideology, cultural ideology to be specific, drives the adaptation and rewriting in translation. In source and target cultures, different norms of adult-child co-sleeping lead to the cover substitution for the picture book A New Year's Reunion and different norms of father-daughter bond triggers plot adaptation for the adolescent fiction Bronze and Sunflower. The article further points out that conforming to target culture and considering target readers' tolerance are principal contributors to the success of these two books in western world. Under the background of Chinese children's literature going global, this article attempts to shed some light on Chinese-to-English translation practice of children's literature.
\end{abstract}

Keywords: Ideological Manipulation, Children's Literature Translation, Rewriting, Norm

\section{Introduction}

Although it occupies an important position of literary and translation practice, translated children's literature (TChL) has always been marginalized in literary translation studies. Translating children's literature is by no means as easy as people have assumed. First of all, translators should acquire a specific knowledge of all the features and functions of different genres of children's literature. Secondly, because of the limited language skills and cognitive abilities of children, translators should pay special attention to language usage and lexical choices. Thirdly, because of the educational function children's literature performs, translators are required to delete taboos, adapt some improper moral and ethical issues to comply with target culture. Under the multiple requirements of young readers, as well as strict censorship of children's literature, translators often make adjustments to language and plot. Just as Stolze states, "The starting point of an approach to translating for children is often a view of translation as rewriting for different audiences in different times, places, and cultures" [1]. It is commonly acknowledged that translation is a form of rewriting, and this is no different for children's books. Translation reflects a certain degree of ideological manipulation of the source text in order to either conform to the norms of the target culture or serve some ideological purposes.

Scholars probe into ideological manipulation in TChL at both micro and macro levels. Some investigate from a text-oriented approach that based on linguist and discursive components to investigate how the ideological manipulation of originals leads to adaptation in translations [2]. Some adopt a extra-textual approach to investigate the social-cultural ideological norms behind translations and how they manifest themselves in certain times, places and genres [3]. Both the bottom-up and top-down approaches help to present a clear picture of how ideology intervenes in translation activities. As a supplement to current studies, this article takes two Chinese books for young readers as case studies, aimed at showing how ideological manipulation in English translation leads to the substitution of the picture book's cover and the purification of the adolescent fiction's plot to fit the norms of the target culture. 
Translation studies of children's literature in China didn't gain much attention until recently. However, among the few studies that have been done, most focus on English-to-Chinese translation strategies of award-winning picture books or canonized adolescent fictions. Such a situation may be attributed to the fact that in Chinese book market the imported children's books from the western world greatly outnumber the exported ones. Despite the fact, more and more excellent Chinese original works have been translated to English and accepted by western young readers. What adaptations do translators make to fit the norm of target culture so as to achieve better reception? What kind of socio-cultural factors lead to these adaptations? The present study is to answer the above questions by conducting a descriptive study, attempting to shed some light on Chinese-to-English translation practice of children's literature.

\section{Ideological Manipulation}

The concept of ideology has a long history, and opens to many different interpretations. The word was first coined by French philosopher Destutt de Tracy in 1796 [4], with a category of philosophical epistemology. Later Simpson defined ideology as the "tacit assumptions, beliefs and value systems, which are shared collectively by social groups" [5]. On the whole, ideology refers to the collective beliefs of a society and on which a political or economic system is based. But this collection of beliefs are sometimes regarded with negative connotations, because ideology is defined as "a system of false distorted or otherwise misguided beliefs" [6].

The great scholar applying the concept of ideology to translation studies is Lefevere. He goes beyond the confines of linguistic framework of translation studies and places great emphasis on the role of ideology in translation activities. In his view, ideology consists of "opinions and attitudes deemed acceptable in a certain society at a certain time, and through which readers and translators approach texts" [7]. He regards translation as rewriting and emphasizes that a translator frequently rewrites the original text because he is manipulated by the three important constraints: ideology, poetics and patronage [8].

Therefore, ideology is one of the many factors influencing translators' work. Ideology in translation studies is subject to two different connotations. Some studies regard "ideology" as political environment in a certain historical period while the others regard it as socio-cultural environment in different countries. The present study takes the latter connotation. As translators' work is always affected by the surrounding socio-cultural environment, ideological beliefs are reflected in language usage. Rewriting and adaptation in translation are driven by different moral and ethical values in the source and target cultures. As Puurtinen argues "It seems to be a general trend in the translation of children's literature that conformity to the norms and conventions of the target language (TL) children's literature takes precedence over 'faithfulness' to the original" [9]. Traces of ideological manipulation can be easily found in TChL. This view is supported by the results of my comparison of two Chinese children's literature works with their English translations.

\section{A New Year's Reunion}

A New Year's Reunion is an English translation of Chinese picture book Tuan Yuan (《团圆》) written by Yu Li-qiong and illustrated by Zhu Cheng-liang. The book tells a story about family reunion during Chinese New Year from the perspective of a little girl, Maomao. Knowing that her father, a migrant worker, is coming home to celebrate New Year with the family, Maomao is rather shy and anxious. But later on, she is attached to her father after doing a series of family activities together, such as making sticky rice balls, hearing the firecrackers, paying new year visits and fixing things around the house. When the father has to go back to work, Maomao gives him the lucky coin she gets from the sticky rice ball as a goodbye gift.

The Chinese original was first published in Taipei, China, in 2008 and has won Feng Zikai Chinese Children's Picture Book Award for its touching story and delicate pictures. Its English version was published by Candlewick Press in 2013. The book is recommended on its cover as A New York Times Best Illustrated Children's Book and An American Library Association Notable Children's Book. It depicts real life of migrant families in modern China, focuses on family affection and features Chinese culture. Therefore, it is highly awarded in target culture.

The most obvious adaptation the translator has made can be found on the front cover (Figures 1-2). On the cover of Chinese version, Maomao is sleeping tucked between her parents, which depicts a warm scene of Chinese family reunion. "Adult-child co-sleeping is the mainstream sleeping arrangement for children in mainland China" [10]. But in western world children usually sleep in their own bedrooms at an early age. The co-sleeping scene on the cover may lead to confusion, upset or even resistance of young target readers. So the translator substitutes the co-sleeping picture with a picture of the family making sticky rice balls together, which not only presents the theme of family reunion but also highlights cultural elements. It is a successful example of a translation conforming to target cultural norms.

Another adaptation can be found in the translation of the title. The Chinese title can literally be translated as "Reunion", but the translator, on the other hand, takes culture into account and translates it into "A New Year's Reunion", which makes the theme of the original more clear. The translation here confirms Shoshana Blum-Kulka's "explicitation hypothesis" [11]. Translators tend to add more information to make translation more intelligible and acceptable for target readers. Here, explicit translation is applied to magnify the background of the story. 


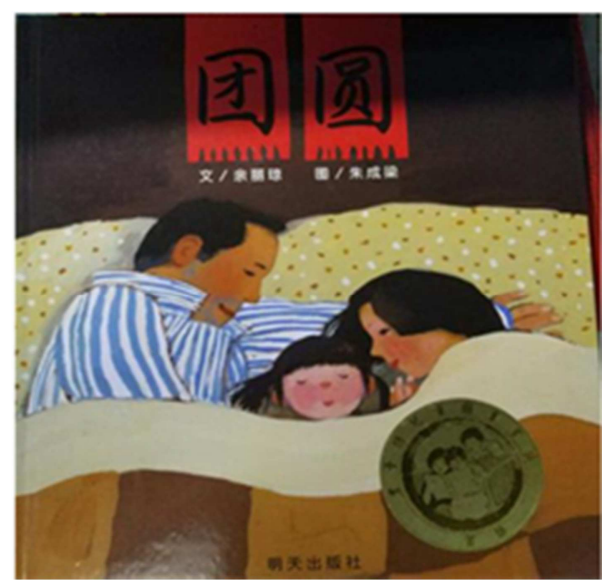

Figure 1. The Cover of Chinese Version [12].

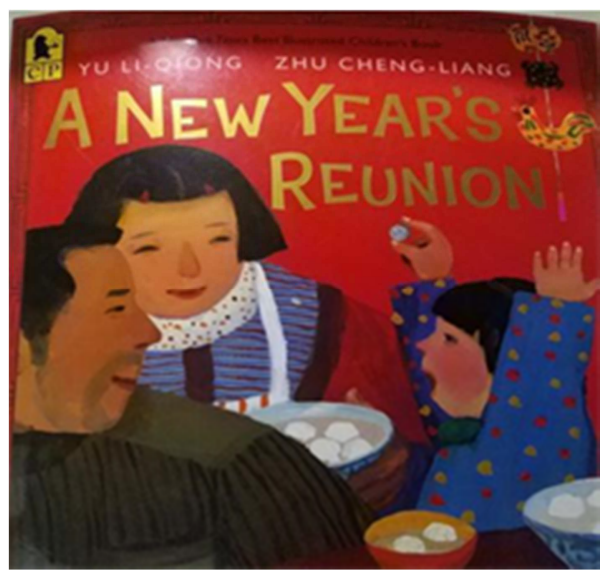

Figure 2. The Cover of English Version [13].

\section{Bronze and Sunflower}

Bronze and Sunflower is an adolescent fiction written by prestigious Chinese writer Cao Wenxuan. Set in the rural areas of Northern Jiangsu province during the Cultural Revolution (1966-1976), the book tells the story of two siblings, Bronze and Sunflower. Bronze is a deaf-mute cowherd boy who lives in a poverty-stricken family. Sunflower is a smart girl whose father, an artist from the city, dies in an accident. Sunflower is orphaned but luckily she is adopted by Bronze family. During the special period, the poor family is stricken by a fire, a food shortage, and a locust plague in a row. Despite abject poverty and successive disasters, all the family members, Nainai, Mama, Baba, Bronze and Sunflower, always unite as one and keep optimistic about life.

The Chinese original Qingtong Kuihua (《青铜葵花》)was first published in China in 2005 and has won several of China's most prestigious awards for children's literature, such as the Song Qingling and Bing Xin Prizes, for its literary qualities and educational values for teenagers. Its English translation, Bronze and Sunflower, was first introduced to English-speaking world in 2015, translated by a British sinologist Helen Wang and published by Walker Books. Its English translation has won a PEN Translation Award and partly due to its' good reception in western world, the writer
Cao Wenxuan has won the Hans Christian Anderson Award, the world's top prize in the field of children's literature.

The translation is well accepted by target readers, partly because of its high literary values and universal theme, partly because of the skillful translation strategies. Just as Helen Wang states in an interview, "Chinese stories often provide more information, and more repetition, than the English reader is used to. It doesn't mean that one style is better than another, but rather that we have different expectations and tolerances" [14]. The translator takes readers' expectations and tolerances into account and hence adapts some plots which are regarded conflict with western moral values. In Bronze and Sunflower, some deleted and adapted scenes include Sunflower's father describing her scent and the father bathing his daughter, as the following passages show:

Chinese

他比熟悉自己还要熟悉女儿。熟悉她的脸、胳膊与腿, 熟悉她的脾气, 熟悉她的气味。直到今天, 她的身上还散 发着淡淡的奶香味, 尤其是在她熟睡的时候, 那气味会 像一株植物在夜露的浸润下散发气味一般, 从她的身上散 发出来。他会用鼻子, 在她裸露在被子外面的脸上、胳膊 上、轻轻地嗅着。他小心翼翼地将她的胳膊放进被窝里。 [15]

\section{English}

He knew her better than he knew himself. He knew her face, her arms and legs, her temperature. Recently he'd been working so hard that he mostly saw her when she was asleep, when he tucked her arms under the cover. [16]

Chinese

他在给女儿洗澡, 看到女儿没有一丝瘢痕的身体时, 心 里会泛起一股说不出的感动。[15]

English

In daylight, when he saw her skin as flawless as the purest white jade, the thought of even a scratch on it tormented him.[16]

A comparison of the two pairs of fragment demonstrates once again deletion and tone-down of taboos in translation. When children's texts travel between countries and cultures, norm conflicts emerges. What is acceptable in Chinese culture may be offensive in western world. Because Sunflower loses her mother at an early age, she and her father are very close to each other. The single father and the young daughter attach to each other and establish intimate bonds. In China, it's normal for a father puts his daughter to bed so sometimes he can smell her scent. Also, it is not abnormal for a father to bathe his preschool daughter. But in western world, children sleep on their own and they bathe themselves at an early age. As Clayton states, "Societies will have differing perspectives on how intimacy should be displayed between parents and children" [17]. In English translation, too intimate father-daughter bond may lead to ethical problems. To avoid this possible controversy, the translator replaces "father smelling his daughter" with "father working late", "father bathes his daughter" with "in daylight". These expressions are much safer and easier to be accepted in target culture. These examples of manipulation in translation also reflect different levels of father-daughter intimacy in different 
cultures.

\section{Conclusion}

Based on the previous analysis in this paper, it is proved that rewriting and adaptation in TChL are driven by many factors, with ideological considerations one of them. Changes are made in TChL with the ideological aim of shifting, diminishing and cutting original norms and values and adding 'correct' norms and values to suit the target culture. In the above examples, adult-child co-sleeping and too intimate father-daughter bond are considered immoral and unethical in target culture and hence are deleted and toned down in translation. Conforming to target culture and considering target readers' tolerance are principal contributors to the success of A New Year's Reunion and Bronze and Sunflower. But it is worth noting that too much ideological manipulation in translation may lead to significantly crucial omissions of messages. As Leonardi puts, "Although the adaptation of the ST to the needs and expectations of the target audience may be considered to be necessary, such a strategy should not be arbitrary and translators should justify their choices" [18]. If ideological manipulation is taken to extremes in translation, it becomes a tool of cultural hegemony, ending up as an obstacle to intercultural exchange.

\section{Acknowledgements}

This research was supported by the 2019 Guangdong Youth Innovative Talents Project "A Study on the English Translation of Chinese Children's Literature in the New Century from the Perspective of Systematic Functional Linguistics" (2019GWQNCX156); 2019 Zhanjiang Preschool Education College Project "Translation Studies on Picture Books from the Perspective of Multimodality" (ZJYZYB201904); An Empirical Study on the Effect of Continuation Task in Junior Middle School Based on Discourse Analysis (2018ZQJK047-3).

\section{References}

[1] Stolze, R. (2003). Translating for Children: World View or Pedagogics? Meta, 48 (1-2), 208-221.

[2] Kaniklidou, T. House, J (2018). Discourse and ideology in translated children's literature: a comparative study. perspectives, 26 (2), 232-245.
[3] Alsiary, H. (2016). Mapping the Field of Children's Literature Translation in Saudi Arabia: Translation Flow in Accordance with Socio-Cultural Norms. England: The University of Leeds.

[4] Munday, J. (2007). Translation and ideology: a textual approach, The Translator, 13 (2), 195-217.

[5] Simpson, P. (1993). Language, ideology and point of view. London/New York: Routledge.

[6] Pérez, M. C. (2003). Apropos of ideology: Translation studies on ideology-Ideologies in translation studies. Manchester, UK \& Northampton MA: St. Jerome Publishing.

[7] Bassnett, S. and Lefevere, A. (1998). Constructing cultures: essays on literary translation (topics in translation). Philadelphia: Multilingual Matters.

[8] Lefevere, A. (1992). Translating, Rewriting, and the Manipulation of Literary Fame. London/New York: Routledge.

[9] Puurtinen, T. (1995). Linguistic Acceptability in Translated Children's Literature. Joensuu: University of Joensuu.

[10] Chou, Wan-Hsiang. (2009). Co-sleeping and the Importation of Picture Books About Bedtime. Children's Literature in Education, 40: 19-32.

[11] Blum-Kulka, Shoshana. (2004). Shifts of Cohesion and Coherence in Translation. In Lawrence Venuti (Ed.), The Translation Studies Reader, $2^{\text {nd }}$ ed (pp. 290-305). New York, London: Routledge.

[12] Yu, L. Q. and Zhu. C. L. (2008). Reunion. Jinan: Tomorrow Publishing House. (in Chinese).

[13] Yu, L. Q. and Zhu, C. L. (2013). A New Year's Reunion. Somerville: Candlewick Press.

[14] Zoe. (2015, 27 April). An interview with the translator of Bronze and Sunflower by Cao Wenxuan. Retrieved 6 August 2020 from http://www.playingbythebook.net/2015/04/27/an-interview-wi th-the-translator-of-bronze-and-sunflower-by-cao-wenxuan/.

[15] Cao Wenxuan. (2005). Bronze and Sunflower. Nanjing: Phoenix Juvenile and Children's Publishing Ltd. (in Chinese).

[16] Cao, Wenxuan. (2015). Helen Wang trans. Bronze and Sunflower. London: Walker Books.

[17] Clayton, C. (2014). 'With my parents I can tell them anything' intimacy levels within British Chinese families. International Journal of Adolescence and Youth, 19 (1): 22-36.

[18] Leonardi, V. (2020). Ideological Manipulation of Children's Literature Through Translation and Rewriting: Travelling Across Times and Places. Switzerland : Palgrave Macmillan. 